\title{
NOTE
}

\section{THE U.N. CONVENTION ON THE RECOGNITION AND ENFORCEMENT OF FOREIGN ARBITRAL AWARDS AND ISSUE PRECLUSION: A TRADITIONAL COLLATERAL ESTOPPEL DETERMINATION}

\author{
Sabrina M. Sudol
}

\section{INTRODUCTION}

Although the United Nations Convention on the Recognition and Enforcement of Foreign Arbitral Awards provides for the "recognition" and "enforcement" of non-domestic arbitral awards in commercial disputes, ${ }^{1}$ this article will show that in order for an issue resolved through arbitration to be granted preclusive effect in subsequent litigation in the United States, the proponent must also satisfy the traditional requirements of collateral estoppel. In this way, the Convention's reach is not quite as expansive as a party might

\footnotetext{
* Sabrina M. Sudol received her J.D. degree and a certificate in International and Comparative Law from the University of Pittsburgh School of Law in May, 2004, magna cum laude. She especially thanks Ms. Meryl Macklin and Mr. Joshua A. Hajek for introducing her to this topic and encouraging her to expand on it and Professor Ronald A. Brand for commenting on prior drafts.

1. United Nations Convention on the Recognition and Enforcement of Foreign Arbitral Awards, June 10, 1958 [hereinafter U.N. Convention on Arbitral Awards]. The United Nations Convention on the Recognition and Enforcement of Foreign Arbitral Awards, also known as the New York Arbitration Convention, was completed in New York on June 10, 1958, and was entered into force for the U.S. on June 7, 1959. In 1971, the Convention was codified at 9 U.S.C. $§ 201$ (2000). The remaining sections of chapter two of the Federal Arbitration Act address procedural questions pursuant to the Convention. 9 U.S.C. $\S \S 202-08$ (2000). For clarification, this article cites specific provisions in the Convention rather than the statute in Part II, but retains specific cases' statutory citations where appropriate in Parts III and IV.
} 
expect, for the ensuing judicial analysis often involves complex questions of law and fact while maintaining respect for the favored status of international commercial arbitration. The result is far from per se preclusivity.

Traditionally, the four requirements of collateral estoppel provide rich ground for lawyers' arguments; moreover, there is a dearth of case law addressing issue preclusion by international arbitration. This article endeavors to shed light on the current process undertaken by the United States courts and their resolution of some of these contentious issues. Part I provides a brief background on the preclusion doctrines' purposes and requirements and addresses the historically uneasy relationship between arbitration and adjudication, to resolve the general question of whether arbitral awards can be granted preclusive effect. Part II takes this question into the international arena and discusses the Convention's scheme for recognition and enforcement. Part III individually analyzes the courts' treatment of each of the four requirements of collateral estoppel in determining the preclusivity of domestic and foreign arbitral awards. Part IV concludes by suggesting that an integrated approach can follow the Convention's mandates while upholding the safeguards built into the doctrine of collateral estoppel, as illustrated in the unpublished Hugo Marom cases. ${ }^{2}$ Judicial practice would thereby respect the favored status of international commercial arbitration and the signatories' desire to increase legal stability in today's global economy, without depriving the private parties of their rightful access to the courts.

\section{Arbitration's Historically Uneasy Preclusivity in Subsequent LiTIGATION}

The judicially-created doctrines of issue and claim preclusion are used by courts to limit subsequent adjudication of the same issue or cause of action after the party has had a full and fair opportunity to litigate it: "A fundamental precept of common-law adjudication . . . is that a 'right, question or fact distinctly put in issue and directly determined by a court of competent jurisdiction ... cannot be disputed in a subsequent suit between the same parties or their privies ....",

2. Hugo Marom Aviation Consultants, Ltd. v. Recon/Optical, Inc., No. 87 C 9273, 1991 U.S. Dist. LEXIS 6877 (N.D. Ill. May 20, 1991), and Hugo Marom Aviation Consultants, Ltd. v. Recon/Optical, Inc., No. 87 C 9273, 1992 WL 233942 (N.D. Ill. Sept. 15, 1992).

3. Montana v. United States, 440 U.S. 147, 153 (1979) (quoting S. Pac. R.R. Co. v. United States, 168 U.S. 1, 48-49 (1897)); accord Parklane Hosiery Co. v. Shore, 439 U.S. 322, 326 n.5 (1979); Allen v. McCurry, 449 U.S. 90 (1980). 
and judicial economy: Reaching a final conclusion provides repose for the individuals, consistency and finality for the legal system, and conservation of judicial resources. " Application of both doctrines is central to the purpose for which civil courts have been established, the conclusive resolution of disputes within their jurisdictions, ", yet it must not override the safeguards of due process.

Although similar in function, the preclusion doctrines have different requirements. Under claim preclusion or res judicata, "a final judgment on the merits bars further claims by parties or their privies based on the same cause of action." Under issue preclusion or collateral estoppel, "once an issue is actually and necessarily determined by a court of competent jurisdiction, that determination is conclusive in subsequent suits based on a different cause of action involving a party to the prior litigation." ${ }^{7}$ Thus, the basic elements of collateral estoppel ${ }^{8}$ can be summarized as 1) final and valid judgment; 2) identical issue; 3) fully and fairly litigated; and 4) privity. ${ }^{9}$

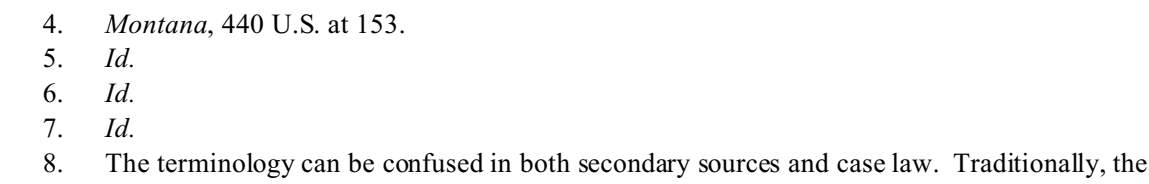
term "res judicata" has two meanings: It can be used broadly - to encompass both preclusion doctrines, as if to say "the matter was decided," and narrowly —as the term for claim preclusion, which prevents the parties from relitigating the same cause of action. Id. "Collateral estoppel" has always referred to issue preclusion. Id. Courts continue to use the Latin terms but attempt to clearly enunciate which definitions they attach to them, and the Supreme Court refers to each in their more narrow meanings of claim preclusion and issue preclusion. Id.

9. In accordance with most federal and state courts, Pennsylvania state law follows the same general requirements for collateral estoppel as the Second Restatement:

1) $[T]$ he issue decided in the prior adjudication must be identical with the one presented in the later action;

2) $[T]$ here must have been a final judgment on the merits;

3) [T] he party against whom collateral estoppel is asserted must have been a party or in privity with the party to the prior adjudication; and

4) [T] he party against whom collateral estoppel is asserted must have had a full and fair opportunity to litigate the issue in question in the prior adjudication.

Witkowski v. Welch, 173 F.3d 192, 199 (3d Cir. 1999). See also Restatement (Second) of Judgments $\S 27$ (1982); cf. Raytech Corp. v. White, 54 F.3d 187, 190 (3d Cir. 1995) (listing four traditional collateral estoppel requirements:

1) the identical issue was previously adjudicated;

2) the issue was actually litigated;

3) the previous determination was necessary to the decision; and

4) the party being precluded from relitigating the issue was fully represented in the prior action). In Zawierucha v. DiMatteo, the Pennsylvania court added a fifth element - the determination in the prior case was essential to the judgment therein — and found that the arbitrator's ruling preclusively decided the issue of the car driver's negligence. Zawierucha v. DiMatteo, No. CIV.A. 00-3198, 2001 WL 1580228, 
Despite some scholarly criticism ${ }^{10}$ and judicial exceptions, ${ }^{11}$ courts use their discretion to assess the elements of both preclusion doctrines and often find them satisfied by the prior arbitration's proceedings. Moore's Federal Practice states, "it is well-settled that the doctrine of issue preclusion is applicable to issues resolved by an earlier arbitration." 12 The Restatement (Second) of Judgments agrees: "[A] valid and final award by arbitration has the same effects under the rules of res judicata [broad definition], subject to the same exceptions and qualifications, as a judgment of a court." ${ }^{\prime 3}$ Yet even when the elements otherwise appear to be satisfied, the Restatement advises against collateral estoppel in some circumstances. ${ }^{14}$ Where the prior proceeding was an arbitration, a court may find "[a] new determination of the issue is warranted by differences in the quality or extensiveness of the procedures followed in the two courts or by factors relating to the allocation of jurisdiction between them[.]" 15 Alternatively, it may find "[t]here is a clear and convincing need for a new determination of the issue ... because it was not sufficiently foreseeable at the time of the initial action that the issue would arise in the context of a subsequent action." "Finally, a court could find "the party ... to be precluded, as a result of the conduct of his adversary or other special circumstances, did not have an adequate opportunity or incentive to obtain a full and fair adjudication in the initial action." 17

Some commentators have noted inherent procedural differences and consequently criticize preclusion by arbitration in subsequent litigation. ${ }^{18}$

at *3 (E.D. Pa. Dec. 10, 2001). As an example of a successful assertion of offensive collateral estoppel by a third party plaintiff based on a prior arbitration under Pennsylvania law, this case also answers the general question of whether arbitral awards can ever be used for collateral estoppel purposes.

10. See infra notes $16-18$ and accompanying text.

11. See infra notes 21-35 and accompanying text.

12. 18 James Wm. Moore et al., Moore’s Federal Practice $\S 132.03[6][f]$ (3d ed. 2002). See also id. § 131.32[3][a].

13. Restatement (SeCond) OF Judgments $\S 84(1)$.

14. Id. $\$ 28$.

15. $I d$.

16. $I d$.

17. Id. The Third Circuit also cautions against overuse:

The Supreme Court has also recognized, however, that collateral estoppel is inappropriate if facts essential to the earlier litigated issue have changed. Finally, in cases involving the offensive use of collateral estoppel, the Supreme Court has instructed that courts must take special care to ensure that its application does not work unfairness to the party against whom estoppel is asserted. Raytech Corp. v. White, 54 F.3d 187, 190 (3d Cir. 1995) (citation omitted).

18. Brian Levine, Civil Procedure Law: Preclusion Confusion: A Call for Per Se Rules Preventing the Application of Collateral Estoppel to Findings Made in Nontraditional Litigation, AnN. SuRv. Am. L. 435 passim (1999); G. Richard Shell, Res Judicata and Collateral Estoppel Effects of Commercial Arbitration, 35 UCLA L. Rev. 623 passim (1988). 
Pointing to language in case law which states that arbitration is binding because it is a creature of contract, they suggest limiting the preclusive effects of an arbitral award to only what the parties actually stipulate within their contract. ${ }^{19}$ However, they acknowledge that the current state of the law is that arbitration can be given preclusive effect. ${ }^{20}$

Historically, arbitration and adjudication have not enjoyed an easy coexistence. The United States Supreme Court explained, "English courts traditionally considered irrevocable arbitration agreements as 'ousting' the courts of jurisdiction, and refused to enforce such agreements for this reason. This view was adopted by American courts as part of the common law up to the time of the adoption of the Arbitration Act." " $[\mathrm{R}]$ eversing centuries of judicial hostility to arbitration agreements," the Federal Arbitration Act of $1947^{22}$ "was designed to allow parties to avoid "the costliness and delays of litigation,' and to place arbitration agreements 'upon the same footing as other contracts ....", 23

However, enforcing agreements to arbitrate and recognizing arbitral awards do not necessitate that arbitral awards will be the final word. Parties may still have their day in court for claims which are outside the scope of the agreement; they may even be permitted to relitigate certain issues which were previously determined by the arbitral panel. In a line of cases involving agreements to submit to domestic arbitration, the Supreme Court has insisted that "it is far from certain that arbitration proceedings will have any preclusive effect on the litigation of nonarbitrable federal claims." ${ }^{24}$ The Full Faith and CreditClause ${ }^{25}$ does not apply to arbitration awards since domestic arbitration

19. Supra note 18.

20. Id.

21. Scherk v. Alberto-Culver Co., 417 U.S. 506, 510 n.4 (1974).

22. Act of July 30,1947 , c. 392,61 Stat. 670 , codified at 9 U.S.C. $\S 1$ et seq.

23. Scherk, 417 U.S. at 510-11 (quoting H.R. ReP. No. 96, 68th Cong., 1st Sess., 1, 2 (1924)).

24. Dean Witter Reynolds Inc. v. Byrd, 470 U.S. 213, 222 (1985) (compelling domestic arbitration in SEC action).

25. The Full Faith and Credit Clause is contained in 28 U.S.C. $\S 1738$ (2004):

The Acts of the legislature of any State, Territory, or Possession of the United States, or copies thereof, shall be authenticated by affixing the seal of such State, Territory or Possession thereto. The records and judicial proceedings of any court of any such State, Territory or Possession, or copies thereof, shall be proved or admitted in other courts within the United States and its Territories and Possessions by the attestation of the clerk and seal of the court annexed, if a seal exists, together with a certificate of a judge of the court that the said attestation is in proper form. Such Acts, records and judicial proceedings or copies thereof, so authenticated, shall have the same full faith and credit in every court within the United States and its Territories and Possessions as they have by law or usage in the courts of such State, Territory or Possession from which they are taken. 
is not a judicial proceeding, an act of a state legislature, or a record of a state court. ${ }^{26}$ Consequently, "[b]ecause federal courts are not required by statute to give res judicata or collateral-estoppel effect to an unappealed arbitration award, any rule of preclusion would necessarily be judicially fashioned."27 Yet the Supreme Court has repeatedly "declined . . . to fashion a federal common-law rule of preclusion" regarding the effects of an unconfirmed domestic arbitral award, ${ }^{28}$ instead, "[lower] courts may directly and effectively protect federal interests by determining the preclusive effect to be given to an arbitration proceeding." ${ }^{29}$ They should therefore compel agreements to arbitrate without fearing the awards will bar subsequent suits:

Significantly, . . . courts may directly and effectively protect federal interests by determining the preclusive effect to be given to an arbitration proceeding. Since preclusion doctrine comfortably plays this role, it follows that neither a stay of the arbitration proceedings, nor a refusal to compel arbitration of state claims, is required in order to assure that a precedent arbitration does not impede a subsequent federal-court action. The Courts of Appeals that have assumed collateral-estoppel effect must be given to arbitration proceedings have therefore sought to accomplish indirectly that which they erroneously assumed they could not do directly. ${ }^{30}$

In Dean Witter Reynolds Inc. v. Byrd, the issue of collateral estoppel was not before the Court; nevertheless, it took the opportunity to reiterate the test it had established in prior case law:

The question of what preclusive effect, if any, the arbitration proceedings might have is not yet before us, however, and we do not decide it. The collateral-estoppel effect of an arbitration proceeding is at issue only after arbitration is completed .... Suffice it to say that in framing preclusion rules in this context, courts shall take into account the federal interests warranting protection. As a result, there is no reason to require that district

26. McDonald v. City of W. Branch, 466 U.S. 284, $287-88$ (1984) (citing Kremer v. Chemical Constr. Corp., 456 U.S. 461, 477 (1982), and declining to grant collateral estoppel effect from an arbitration, but suggesting its admission into evidence in the subsequent 42 U.S.C. $§ 1983$ suit).

27. Id. at 288 .

28. Dean Witter Reynolds Inc., 470 U.S. at 222 (compelling domestic arbitration in SEC action). The Court reiterated the basis for its holding in McDonald:

We also declined, in McDonald, to fashion a federal common-law rule of preclusion, in part on the ground that arbitration cannot provide an adequate substitute for a judicial proceeding in protecting the federal statutory and constitutional rights that $\S 1983$ is designed to safeguard. We therefore recognized that arbitration proceedings will not necessarily have a preclusive effect on subsequent federal-court proceedings.

Id. at 223 .

29. Id.

30. $I d$. 
courts decline to compel arbitration, or manipulate the ordering of the resulting bifurcated proceedings, simply to avoid an infringement of federal interests. ${ }^{31}$

In the past,"substantial statutory rights" not subject to preclusion by domestic arbitration included Title VII, ${ }^{32}$ the Fair Labor Standards Act ${ }^{33}$ and formerly, SEC actions. ${ }^{34}$ More recently, the Court has not only refused to expand this list but has also stepped back from it, at least with respect to international arbitration: "[W]e are well past the time when judicial suspicion of the desirability of arbitration and of the competence of arbitral tribunals inhibited the development of arbitration as an alternative means of dispute resolution."${ }^{.35}$

\section{The U.N. Convention on Arbitral Awards: Why International Parties Turn to Arbitration to Resolve Commercial Disputes}

In stark contrast to domestic arbitral awards, the Supreme Court has noted strong policy reasons for deference to international commercial arbitration in order to encourage global economics. ${ }^{36}$ The Court stated:

The expansion of American business and industry will hardly be encouraged if, notwithstanding solemn contracts, we insist on a parochial concept that all disputes must be resolved under our laws and in our courts. ... We cannot have trade and commerce in world markets and international waters on our terms, governed by our laws, and resolved in our courts. ${ }^{37}$

However, the presumption favors enforcement of arbitration agreements and recognition of arbitral awards, rather than preclusion per se. ${ }^{38}$

31. Id.

32. Alexander v. Gardner-Denver Co., 415 U.S. 36 (1974).

33. McDonald, 466 U.S. at 284; Barrentine v. Arkansas-Best Freight Sys. Inc., 450 U.S. 728 (1981). For a summary of Supreme Court opinions in this area, see Jane Byeff Korn, Changing Our Perspective on Arbitration: A Traditional and a Feminist View, 1991 U. ILL L. Rev. 67.

34. Dean Witter Reynolds Inc. v. Byrd, 470 U.S. 213 (1985), overruled by Shearson/American Express, Inc. v. McMahon, 482 U.S. 220 (1987) and De Quijas v. Shearson/American Express, 490 U.S. 477 (1989); compare Sherk v. Alberto-Culver Co., 417 U.S. 506 (1974) (requiring the parties to submit to arbitration under the International Chamber of Commerce in Paris, France); Mitsubishi Motors Corp. v. Soler Chrysler-Plymouth, 473 U.S. 614 (1985) (compelling international arbitration of antitrust claims). See also Ronald A. BRAnd, Fundamentals of InTERnATIONAL Business Transactions 560-84 (2000) (discussing enforcement of agreements to arbitrate, particularly in the international arena).

35. Mitsubishi, 473 U.S. at 627-28; see also supra note 34; cf. supra note 14.

36. E.g., Mitsubishi, 473 U.S. at 639; Scherk, 417 U.S. at 519-20; see also J.J. Ryan \& Sons, Inc. v. Rhone Poulenc Textile, S.A., 863 F.2d 315, 319 (4th Cir. 1988).

37. The Bremen v. Zapata Off-Shore Co., 407 U.S. 1, 9 (1972); accord Gen. Elec. Co. v. Deutz AG, 270 F.3d 144, 160 (3d Cir. 2001).

38. See cases cited supra note 36. 
Generally, transnational commercial suits may be in federal court not only on the basis of diversity jurisdiction, ${ }^{39}$ but also under federal subject matter jurisdiction which is conferred by 9 U.S.C. $§ 205$ to actions that "relate[] to" an arbitration agreement that falls under the Convention. ${ }^{40}$ Article I of the Convention governs its applicability:

This Convention shall apply to the recognition and enforcement of arbitral awards made in the territory of a State other than the State where the recognition and enforcement of such awards are sought, and arising out of differences between persons, whether physical or legal. It shall also apply to arbitral awards not considered as domestic awards in the State where their recognition and enforcement are sought. ${ }^{41}$

A contracting state may also require reciprocity or limit the scope of applicability to "differences arising out of legal relationships, whether contractual or not, which are considered as commercial under the national law of the State making such declaration. ${ }^{42}$

Under Article II of the Convention, "[e]ach Contracting State shall recognize an agreement in writing," which is defined as "an arbitral clause in a contract or an arbitration agreement, signed by the parties or contained in an exchange of letters or telegrams, ${ }^{, 43}$ wherein:

... the parties undertake to submit to arbitration all or any differences which have arisen or which may arise between them in respect of a defined legal relationship, whether contractual or not, concerning a subject matter capable of settlement by arbitration. ${ }^{44}$

Either party may request that a court of a contracting state refer the parties to arbitration rather than hearing the action, "unless it finds that the said agreement is null and void, inoperative or incapable of being performed." 45 The Court of Appeals for the Fifth Circuit recently held that, subject to the well-pleaded complaint rule, a suit consisting of only state law claims was removable to federal court due to a remote arbitration clause where the property in dispute was a Hungarian oil field:

[W] henever an arbitration agreement falling under the Convention could conceivably affect the outcome of the plaintiff's case, the agreement "relates to" the plaintiff's suit.

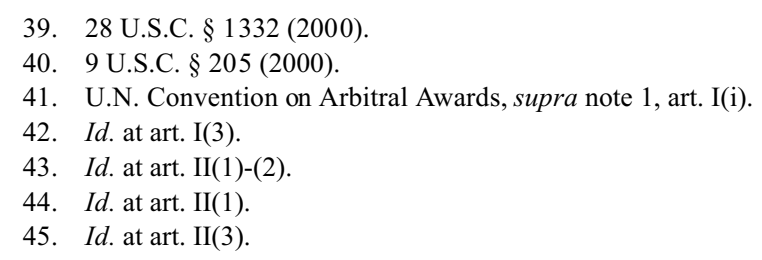


Thus, the district court will have jurisdiction under [9 U.S.C.] $§ 205$ over just about any suit in which a defendant contends that an arbitration clause falling under the Convention provides a defense. As long as the defendant's assertion is not completely absurd or impossible, it is at least conceivable that the arbitration clause will impact the disposition of the case. That is all that is required to meet the low bar of "relates to."46

After the arbitration has concluded, the party applying for recognition and enforcement should supply the court of a contracting state with the original or a copy of the agreement to arbitrate and a duly authenticated original or certified copy of the award, both of which must be translated into an official language of that court's contracting state. ${ }^{47}$ Article III mandates that "[e]ach Contracting State shall recognize arbitral awards as binding and enforce them in accordance with the rules of procedure of the territory where the award is relied upon, under the conditions laid down [in the Convention]" and may not "impos[e] substantially more onerous conditions or higher fees or charges" than it would for domestic arbitral awards. ${ }^{48}$ However, a party may apply "for the setting aside or suspension of the award." ${ }^{49}$ The court has the discretion to order a stay "if it considers it proper [to] adjourn the decision on the enforcement of the award and may also, on the application of the party claiming enforcement of the award, order the other party to give suitable security." ${ }^{50}$

Given the primary purpose of encouraging and facilitating international commercial arbitration, the applicable federal statute for enforcement and recognition codifies the Convention's limited grounds for refusal or modification of an arbitral award. ${ }^{51}$ Some of the listed justifications are

46. Beiser v. Weyler, 284 F.3d 665, 669 (5th Cir. 2002).

47. U.N. Convention on Arbitral Awards, supra note 1, art. IV(1)-(2).

48. Id. at art. III.

49. Id. at art. VI.

50. Id.

51. See 9 U.S.C. $\S \S 201-08$ (2000) and U.N. Convention on Arbitral Awards, supra note 1, art. V(1)-(2). It should be noted that unlike foreign arbitral awards, other countries' judgments are not covered by federal statute, and consequently are not afforded the same level of deference in U.S. courts. While the Convention imposes mandatory recognition and enforcement procedures, comity is a discretionary policy which affords respect to other countries' judgments. The landmark case, Hilton v. Guyot, 159 U.S. 113, 163-64 (1895), sets out the general statement for analysis of enforceability of foreign judgments under comity while denying enforcement of a French judgment due to lack of reciprocity with the United States. In general, subsequent cases have not required reciprocity. See, e.g., Somportex Ltd. v. Phila. Chewing Gum Corp., 453 F.2d 435 (3d Cir. 1971).

Choice of law arguments also figure strongly in a court's use of discretion in recognizing foreign judgments. See Restatement (Second) of Conflict of Laws $§ 98$ (1969); Restatement (ThiRd) of Foreign Relations Law $\S \S 481-483$ (1986); Robert C. Casad, Issue Preclusion and Foreign Country Judgments: Whose Law?, 70 IowA L. REV. 53 (1984). The Informal Working Group of the Hague 
procedural matters. For example, the party against whom enforcement is being invoked could prove that the parties to the agreement were "under some incapacity" under the applicable law, or that the agreement to arbitrate was "not valid under the law to which the parties have subjected it or ... under the law of the country where the award was made." ${ }^{\prime 2}$ Refusal is also proper if the party against whom enforcement is being sought "was not given proper notice of the appointment of the arbitrator or of the arbitration proceedings or was otherwise unable to present his case ....",53 The party may also contest the improper composition of the arbitral authority or the arbitral procedure, if they were "not in accordance with the agreement of the parties, or, failing such agreement, . . . not in accordance with the law of the country where the arbitration took place. ${ }^{" 54}$ Recognition and enforcement are not proper if " $[\mathrm{t}] \mathrm{he}$ award has not yet become binding on the parties, or has been set aside or suspended by a competent authority of the country in which, or under the law of which, that award was made." 55 Parties may also invoke the scope provision to remove any portion of an arbitral award that "deals with a difference not contemplated by or not falling within the terms of the submission to arbitration, or ... decisions on matters beyond the scope of the submission to arbitration ...." ${ }^{56}$ Two other grounds permit refusal if the subject matter of the dispute "is not capable of settlement by arbitration under the law of [the enforcing] country[,]" or if the court deems the award "contrary to [its country's] public policy ...."

Thus under the Convention, res judicata is certain - a future action based on the same claim is precluded if it has been decided in a foreign arbitration. However, collateral estoppel is not necessarily mandated - an issue which has already been determined in a prior arbitration could be relitigated if the new action is based on a different claim. Despite the Convention's semi-automatic provisions for enforcement, this article will show under the case law that its codification does not translate into automatic issue preclusion in subsequent litigation.

\footnotetext{
Judgments Project is currently drafting a proposal which would afford foreign judgments similar treatment to the Arbitration Convention. See Working Document No. 49 of the Special Commission Meeting on Judgments of December 2003, at ftp://ftp.hcch.net/doc/workdoc49e.pdf (last visited on Feb. 25, 2004).

52. U.N. Convention on Arbitral Awards, supra note 1, art. V(1)(a).

53. Id. at art. $\mathrm{V}(1)(\mathrm{b})$

54. Id. at art. $\mathrm{V}(1)(\mathrm{d})$.

55. Id. at art. $\mathrm{V}(1)(\mathrm{e})$.

56. Id. at art. $\mathrm{V}(1)(\mathrm{c})$.

57. Id. at art. $\mathrm{V}(2)$.
} 


\section{Individual Elements of Collateral Estoppel Analyzed Within Case Law: The Convention Militates a Different Approach}

\section{A. Final and Valid Judgment}

In general, a federal court's assessment of "[w] $[w e t h e r$ a judgment should be considered final for the purposes of collateral estoppel 'turns upon such factors as the nature of the decision (i.e., that it was not avowedly tentative), the adequacy of the hearing, and the opportunity for review.",58

Many cases stand for the rule that it is the judicial confirmation of the arbitral award that affords preclusive effect, not the award itself. ${ }^{59}$ Similarly, the U.N. Convention states that once an arbitral award has been confirmed or finalized in a foreign court, it should be construed as a final judgment and is worthy of recognition and enforcement by signatory countries unless one of the few narrow exceptions laid out in Article V exists. ${ }^{60}$ However, there is a

58. Glictronix Corp. v. AT\&T Co., 603 F. Supp. 552, 573 (D. N.J. 1994) (quoting Lummus Co. v. Commonwealth Refining Co., 297 F.2d 80, 89 (2d Cir. 1961), cert. denied, 368 U.S. 986 (1962)) (addressing an administrative decision).

59. E.g., Gruntal \& Co. v. Steinberg, 854 F. Supp. 324, 337 (D. N.J. 1994) (stating it is the judicial confirmation, not the arbitral award, that can be given preclusive effect); Wurttembergishe Fire Ins. Co. v. Republic Ins. Co., No. 86 Civ. 2696 (CSH), 1987 WL 19288 (S.D.N.Y. Oct. 28, 1987) (denying collateral estoppel where party dropped confirmation proceedings); $c f$. Kremer v. Chem. Constr. Corp., 456 U.S. 461 (1982) (finding that an administrative decision warranted res judicata effect in federal court under full faith and credit once it had been confirmed in state court).

An example of a successful defensive use of an arbitral award for collateral estoppel purposes, Witkowski v. Welch involved a domestic award that had been confirmed in district court pursuant to 9 U.S.C. § 13. Witkowski v. Welch, 173 F.3d 192 (3d Cir. 1999). The Court of Appeals for the Third Circuit stated that once confirmed, an arbitral award should be given the same enforcement as any other judgment from the rendering court. $I d$. at 200. The plaintiff, Witkowski, brought fraud and ERISA claims against defendants Welch and Shreim. Id. at 195. These claims went to arbitration, where the fraud claims were dismissed with prejudice and the ERISA claim was determined in plaintiff's favor. $I d$. at 195-97. The plaintiff then sought to relitigate the fraud claims in subsequent litigation, and the district court "confirmed the arbitrator's award in all respects," then later granted summary judgment in favor of the defendants on collateral estoppel grounds. $I d$. at 195 . The court of appeals upheld the district court's summary judgment, finding that once the arbitration award had been confirmed in district court, it was a final judgment on the merits. Id. at 200. Also, the issues were the same in both actions, the party (appellant Witkowski) against whom collateral estoppel was being asserted was a party (plaintiff) to the prior proceeding, and the parties had a full and fair opportunity to litigate the issues in the prior arbitration. Id.

60. Supra notes 47-56 and accompanying text. A related issue is whether the United States court should recognize and enforce an arbitral award which has been annulled in a foreign country. In Chromalloy Aeroservices v. Arab Republic, the court considered this issue of first impression and confirmed and enforced the international commercial arbitral award despite its nullification by the Egyptian Court of Appeals. 939 F. Supp. 907, 914-15 (D.D.C. 1996). However, later cases have yielded the opposite result. See Baker Marine, Ltd. v. Chevron, Ltd., 191 F.3d 194, 196-98 (2d Cir. 1999) (distinguishing Chromalloy and refusing confirmation of Nigerian arbitral awards which had been nullified in Nigerian 
limit to the action a United States court can take: The corresponding statute confers federal subject matter jurisdiction, but does not provide an exception to the required personal jurisdiction. ${ }^{61}$ Thus, only if the district court has jurisdiction over the parties may the award be confirmed against them. ${ }^{62}$

In a recent Second Circuit case in which the court reviewed a district court's confirmation of an American Arbitration Association (AAA) arbitration, federal subject matter jurisdiction was proper under the Convention because it met the three jurisdiction requirements of 9 U.S.C. $\S 203$ : "[T] he award (1) must arise out of a legal relationship (2) which is commercial in nature and (3) which is not entirely domestic in scope." ${ }^{93}$ The court then explained the applicable review of confirmations:

In reviewing a district court's confirmation of an arbitral award, we review legal issues de novo and findings of fact for clear error. Federal court review of an arbitral judgment is highly deferential; such judgments are to be reversed only where the arbitrators have exceeded their authority or made a finding in manifest disregard of the law. "[A]s long as the arbitrator is even arguably construing or applying the contract and acting within the scope of his authority, that a court is convinced he committed serious error does not suffice to overturn his decision." "[C]ourts may vacate awards only for an overt disregard of the law and not merely for an erroneous interpretation .... Moreover, the law ignored by the arbitrators must be well-defined, explicit, and clearly applicable if the award is to be vacated." ${ }^{\prime 64}$

Even though appellate review under the Convention is highly deferential, this deferential standard of review for recognition and enforcement does not necessarily extend to a court's subsequent independent inquiry into whether the arbitration's determination of a particular issue will be deemed final and conclusive between the parties. Furthermore, the right of appeal of the confirmation proceeding may provide further due process safeguards.

\section{B. Identical Issue}

The issue of fact or law sought to be precluded must be identical in both proceedings. ${ }^{65}$ Despite the apparent simplicity of this requirement, it is

\footnotetext{
courts); Karaha Bodas Co. v. Negara, 335 F.3d 357 (5th Cir. 2003).

61. See 9 U.S.C. $\S \S 201,203,207$ (2000). 2002)

62. Glencore Grain Rotterdam B.V. v. Shivnath Rai Harnarain Co., 284 F.3d 1114, 1121 (9th Cir.

63. Pike v. Freeman, 266 F.3d 78, 85 n.4 (2d Cir. 2001).

64. Id. at 86 (citation omitted) (quoting United Paperworkers Int'l Union, AFL-CIO v. Misco, Inc., 484 U.S. 29, 38 (1987); Folkways Music Publishers, Inc. v. Weiss, 989 F.2d 108, 111-12 (2d Cir. 1993)).

65. Despite prior case law, most modern courts, including the Supreme Court, have said that
} 
actually highly contestable. The party opposing collateral estoppel can argue that the issues, even though facially identical, are different because the first dispute focused on different nuances in order to prove the other cause of action, or because the identities of the parties make the issues different where privity is claimed or nonmutual use of collateral estoppel is asserted. ${ }^{66}$ The following example illustrates one court's determination that this requirement has been met by the foreign arbitration. Stating, "[a]11 of the plaintiffs' claims raise but a single issue: the right of the Norrises to participate in the continued profits of Twining Tea's United States distributorship. That issue has already been decided at the Norris-Cooper arbitration proceeding[,]" the court rejected the plaintiffs' arguments that the issues were not identical:

We also find no merit in the Norrises' argument that collateral estoppel should not apply because the remedy sought in this action differs from the one obtained in the arbitration proceeding. As the district court found, the remedies sought in both proceedings were identical. Plaintiffs should not be given a second chance to litigate the same issue. The fact that plaintiffs base their claims on new legal theories does not shield them from the doctrine of collateral estoppel, as liability is premised on the same issue in both proceedings. ${ }^{67}$

Frequently, the lack of written findings or opinions explaining an arbitral award makes it more difficult to determine whether the issue in the second suit is actually identical to the first suit. However, the absence of a written opinion is not necessarily fatal, because "[i]n determining which issues have been actually litigated, the federal court is free to go beyond the judgment and may examine the pleadings and the evidence in the prior action." ${ }^{\prime 6}$ In addition, parties can submit parol evidence to show that the arbitrator reached the issues sought to be precluded. ${ }^{69}$ At least one court has said it is even permissible to make inferences, although any ambiguity must be resolved against collateral estoppel: "When the issue for which preclusion is sought is

collateral estoppel may apply to questions of law as well as issues of fact as a general matter. E.g., Montana v. United States, 440 U.S. 147, 162-63 (1979). See Market St. Ltd. Partners v. Englander Capital Corp., No. 92 Civ. 7434 (LMM), 1993 WL 276062 (S.D.N.Y. July 21, 1993). However, offensive use of collateral estoppel would be "inappropriate where " $[\mathrm{t}$ ]he issue is one of law and treating it as conclusively determined would inappropriately foreclose opportunity for obtaining reconsideration of the legal rule on which it was based." Glictronix Corp. v. AT\&T Co., 603 F. Supp. 552, 571 (D. N.J. 1994) (quoting Rest A AEMENT (SECOND) OF JudGMENTS § 27(7)) (addressing an administrative decision).

66. See Restatement (Second) of Judgments $\$ 27 \mathrm{cmt}$. c.

67. Norris v. Grosvenor Mktg. Ltd., 803 F.2d 1281, $1285-86$ (2d Cir. 1986) (internal citations omitted).

68. MoOre ET AL., supra note $12, \S 132.03[2][\mathrm{b}]$.

69. Slavin v. Benson, 493 F. Supp. 32, 35 (S.D.N.Y. 1980). 
the only rational one the fact finder could have found, then that issue is considered foreclosed, even if no explicit finding of that issue has been made." $" 70$

The issue may not be deemed identical where there is a difference in the forums in which the two actions are to be determined ${ }^{71}$ or where the standard of proof varies. ${ }^{72}$ Although collateral estoppel has been denied where the party seeking preclusion based on a domestic arbitration was unable to show that the standard of proof applied by an arbitrator was identical to that of the state or federal forum, ${ }^{73}$ vast differences in various nations' substantive law and procedures could obliterate any possibility of an international arbitral award's preclusive effect if courts insisted on a complete identity between the forums. Thus, cases involving foreign arbitration should also factor in the need for comity ${ }^{74}$ as well as Hilton v. Guyot's oft-quoted standard governing recognition of foreign judgments:

[W] here there has been opportunity for a full and fair trial abroad before a court of competent jurisdiction, conducting the trial upon regular proceedings, after due citation or voluntary appearance of the defendant, and under a system of jurisprudence likely to secure an impartial administration of justice between the citizens of its own country and

70. Clark v. Bear Stearns \& Co., 966 F.2d 1318, 1321 (9th Cir. 1992); Moore ET AL., supra note $12, \S 132.03[2][\mathrm{d}]$. See also Restatement (Second) of Judgments $§ 27$.

71. Glictronix, 603 F. Supp. 552. See also Norrell Health Care, Inc. v. Clayton, 168 B.R. 700 (Bankr. N.D. Ca. 1994) (examining the proceedings closely to determine whether the issue was necessary to the decision, but declining to apply collateral estoppel preclusion partly out of concern for state law differences and uncertainty of standard of proof applied).

72. E.g., Clark v. Bear Stearns \& Co., 966 F.2d 1318 (9th Cir. 1992) (stating no preclusion of securities fraud issue due to uncertain identity of issues and different standard of proof); Steelmet, Inc. v. Caribe Towing Corp., 747 F.2d 689 (11th Cir. 1984) (holding arbitration had different burden of proof than trial); Lynne Carol Fashions, Inc. v. Cranston Print Works Co., 453 F.2d 1177 (3d Cir. 1972) (landmark case holding that the issues regarding quality of the cloth were not identical due to different liability and causation); Osuala v. Cmty. Coll. of Phila., No. CIV. A. 00-98, 2000 U.S. Dist. LEXIS 11609, at *14-*15 (E.D. Pa. Aug. 15, 2000) (stating that preclusive effect of arbitration is "permissible, but not mandatory," and denying it because the issue was not identical); Rep. of Phillippines v. Westinghouse Elec. Corp., 782 F. Supp. 972 (D. N.J. 1992) (holding issues were not identical in both actions because the tribunal applied a higher standard of proof and the counts of conspiracy were broader in the second action; in addition, privity was not satisfied); Forbo-Giubiasco S.A. v. Congoleum Corp., 516 F. Supp. 1210 (S.D.N.Y. 1981) (holding that sister companies were in privity but the different contracts made the issues not identical).

73. Supra note 72. See also Restatement (Second) OF Judgments $§ 29$ (listing factors that may mitigate against preclusion, including the second forum affording additional procedural opportunities); MOORE ET AL., supra note 12, $\$ 131.32$ (discussing how the "[n]ature of [the] prior tribunal may affect claim preclusion").

74. Comity is the "recognition which one nation allows within its territory to the legislative, executive or judicial acts of another nation, having due regard both to international duty and convenience, and to the rights of its own citizens or of other persons who are under the protection of its laws." Hilton v. Guyot, 159 U.S. 113, 164 (1895). 
those of other countries, and there is nothing to show either prejudice in the court, or in the system of laws under which it was sitting, or fraud in procuring the judgment, or any other special reason why the comity of this nation should not allow it full effect, the merits of the case should not, in an action brought in this country upon the judgment, be tried afresh $\ldots{ }^{75}$

\section{Fully and Fairly Litigated}

In order to be "fully and fairly litigated," actual resolution of the issue must have been necessary to the outcome of the award, but "the failure of the arbitrator to render detailed findings of fact and conclusions of law does not render the award ambiguous": ${ }^{76}$

First, the issue dispositive of the present action must have been necessarily decided in the prior action. This does not mean that the prior decision must have been explicit. "If by necessary implication it is contained in that which has been explicitly decided, it will be the basis for collateral estoppel."

Due process demands that any party to be precluded must have had a full and fair opportunity to air the relevant evidence; arbitration proceedings as a whole are most likely to be attacked on the basis of this element. Parties usually elect in their contracts which rules of arbitration will be applied. For example, domestic arbitration agreements commonly select the American Arbitration Association, whose procedures may be inadequate to bar subsequent litigation; in the past, courts have declined preclusive effect where the tribunal did not provide for a final written opinion or findings, extensive discovery, authority to subpoena witnesses, cross examination of witnesses, lawyers representing the parties, or a final right of appeal. ${ }^{78}$ Courts have also denied preclusivity in cases in which the arbitrator was a shop expert rather than a lawyer or judge, the findings exceeded the scope of arbitrator's authority, the forum was inconvenient, or the stakes were lower in the first

75. Hilton, 159 U.S. at 202-03.

76. Norris v. Grosvenor Mktg. Ltd., 803 F.2d 1281, 1286 (2d Cir. 1986).

77. Id. at 1285 (quoting 5 J. Weinstein et al., New York Civil Practice 5011.27 (1985)).

78. E.g., Gruntal \& Co. v. Steinberg, 854 F. Supp. 324 (D. N.J. 1994) (stating that arbitration procedures do not always provide a full and fair opportunity to litigate, present witnesses, evidence, etc.), aff'd, 46 F.3d 1116 (3d Cir. 1994); Glictronix Corp. v. AT\&T Co., 603 F. Supp. 552 (D. N.J. 1994) (stating Third Circuit rules for collateral estoppel, as well as fairness factors for offensive, nonmutual collateral estoppel); accord, e.g., In re Selmonosky, 204 B.R. 820 (N.D. Ga. 1996) (precluding some issues but not all). But see Greenblatt v. Drexel Burnham Lambert, Inc., 763 F.2d 1352 (11th Cir. 1985); Ivery v. United States, 686 F.2d 410 (6th Cir. 1982) (granting preclusion where procedures were adequate). See generally MOORE ET AL., supra note $12, \S 132.03$. 
action so that there was less incentive to litigate. ${ }^{79}$ In contrast, foreign arbitration panels often follow procedures such as the International Chamber of Commerce (ICC) rules or the UNCITRAL model for international arbitration, ${ }^{80}$ which are much more like adjudication. Moreover, the Convention's list of mandatory and discretionary factors are meant to curtail any judicial bias against international commercial arbitration. ${ }^{81}$

\section{Privity}

Especially in the arbitration context, it may be appropriate to narrowly construe privity. The original parties are bound to arbitration of their disputes because they affirmatively agree to it in their contracts $;{ }^{82}$ however, the original parties' privies do not expressly make such a waiver of judicial remedy.

The day in court ideal pulls so strongly against preclusion that a person who was not a party to the first suit frequently may relitigate legal and factual issues that have already been determined in that suit. It often makes no difference that the nonparty sues about the same set of events, asserts the same legal theories, seeks the same remedies, or shares the same interests in the outcome of the litigation as the plaintiff to the first suit. Nor does it matter that the nonparty and the original plaintiff retain the same attorney or that the nonparty testified at the original trial. Even when the nonparty declines an opportunity to intervene and participate in the first suit, preclusion is rarely allowed. ${ }^{83}$

In order to comport with due process, the party to be estopped must have been fully represented in the prior proceeding, either directly (as the movant's previous adversary) or virtually (through a relationship such that his or her interests have been represented by the losing party). ${ }^{84}$ One commonly

\footnotetext{
79. Supra note 78.
}

80. See Brand, supra note 34, at 585-86; see also Daniel M. Kolkey, It's Time to Adopt the UNCITRAL Model Law on International Commercial Arbitration, 8 TRANSNAT'L L. \& CONTEMP. PRoBS. 3 (1998) (comparing the Federal Arbitration Act (FAA) Model and United Nations Commission on International Trade Law (UNCITRAL) Model).

81. See discussion infra Parts II and III(1) and accompanying footnotes.

82. See U.N. Convention on Arbitral Awards, supra note 1, art. II, see also discussion infra Parts I, II and notes 18-19.

83. Robert G. Bone, Rethinking the Day in Court Ideal and Nonparty Preclusion, 67 N.Y.U. L. REV. 193, 196 (1992) (footnote omitted).

84. For the complete list of such relationships, see Restatement (SECOND) OF Judgments $\S \S 27$, 43-61; 18 Charles Allan Wright, Arthur R. Miller \& Edward H. Cooper, Federal Practice \& Procedure $\S 4457$ ( $2 \mathrm{~d}$ ed. 2002) (explaining the relationships with reference to specific cases applying virtual representation); see also Moldovan v. Great Atl. \& Pac. Tea Co., 790 F.2d 894, 900 (3d Cir. 1986) (holding trustee was not adequately represented by union); Johnson v. United Food \& Commercial Workers, 828 F.2d 961, 966 (3d Cir. 1987) (finding union fairly represented the workers); Collins v. E.I. Dupont de Nemours \& Co., 34 F.3d 172, 177 (3d Cir. 1994) (holding worker was not represented by other employees); 
recurring notion is that the actors are in privity if the second party could be sought for enforcement of the monetary award entered against the original party. ${ }^{85}$ Similarly, privity can be met if the second party directed the arbitration proceedings from behind the scenes, including making legal decisions and financing the original party's legal team. ${ }^{86}$ The factors which support compulsory arbitration and consolidation are also those that support privity. ${ }^{87}$ Again, the idea is that the second party is bound to the decision through its relationship with the original party.

International commercial transactions frequently involve business and property relationships which may give rise to a finding of privity: certain positions within a corporation, members of a partnership, and unincorporated associations; joint and several liability, co-obligors and joint obligees; vicarious liability arising from master/servant, principal/agent, and insurer/insured relationships; concurrent and successive property; transfers and co-owners of property and business arrangements such as assignation, promisee and intended beneficiary of a contract, and indemnification. ${ }^{88}$

Privity may be most often at issue in international commercial dispute resolution where the parties are parent/subsidiaries or brother/sister corporations, or agents of a party to the arbitration. For example, in Usina Costa Pinto S.A. Acucar E Alcool v. Louis Dreyfus Sugar Co., the plaintiff sugar mill brought fraud and related claims against two defendant sugar companies. ${ }^{89}$ Despite the fact that the plaintiff had been unaware of the

Robertson v. Bartels, 148 F. Supp. 2d 443, 450 (D. N.J. 2001) ("holding that [a]ny privity analysis must center on a finding of identity of interests between the parties in the first and second cases[]"), aff' $d, 534$ U.S. 1110 (2002). See generally Behrens v. Skelly, 173 F.2d 715 (3d Cir. 1949) (establishing privity principles for preclusion).

85. See Bone, supra note 83 .

86. Supra note $90 ;$ cf. Bone, supra note 83 , at 236, 280 (finding no personal right to appear in court and advocating instead a case-by-case analysis of the legitimacy of the absent party's claim); Thomas J. Stipanovich, Arbitration and the Multiparty Dispute: The Search for Workable Solutions, 72 Iowa L. Rev. 473, 500-02 (1987) (advocating consolidation in arbitration context).

87. See supra note 84. A good case for illustration is Dayhoff, Inc. v. H.J. Heinz Co., 86 F.3d 1287 (3d Cir. 1996). Even though the subsidiaries were not allowed to force the dispute to arbitration since their contract did not include it, the court stayed action pending arbitration. Id. at 1303. Presumably, the arbitration would have some preclusive or evidentiary effect in subsequent proceedings. Similarly, in Acquaire v. Canada Dry Bottling, 906 F. Supp. 819, 838 (E.D.N.Y. 1995), the court stayed the remaining claims and motions pending outcome of the arbitration because the arbitration would likely determine most of the issues, and in Progressive Casualty Insurance Co. v. C.A. Reaseguradora Nacional de Venezuela, 991 F.2d 42, 49 (2d Cir. 1993), the court stayed judicial proceedings pending arbitration.

88. Restatement (Second) of Judgments $\S \S 43-44,49-61$.

89. Usina Costa Pinto S.A. Acucar E Alcool v. Louis Dreyfus Sugar Co., 933 F. Supp. 1170 (S.D.N.Y. 1996). 
defendants' interrelationship and potential conspiracy until the arbitration was nearly complete, the court did not permit collateral estoppel against the second defendant because it was not a party in the original arbitration proceedings and thus had not defended itself against the claim. ${ }^{90}$ The narrowness of the court's privity analysis may be distinguishable here because the movant sought to preclude conspiracy as well as fraud issues, which directly impacted the due process rights of the second defendant, yet the court did compel further arbitration due to the close relationship of the parties. ${ }^{91}$

\section{The Hugo Marom Example: Integrating the Convention into the Collateral Estoppel Analysis}

The unpublished district court proceedings of Hugo Marom Aviation Consultants, Ltd. v. Recon/Optical, Inc. ${ }^{92}$ illustrate a careful and insightful implementation of the Convention in matters of jurisdiction, recognition, and enforcement, to ultimately permit collateral estoppel of issues which had been determined in arbitration in Israel. In the first proceeding, the foreign arbitral award had not yet been confirmed in the Israeli court, so the Illinois district judge held that it had no preclusive effect on the corporation's counterclaims for wrongful conversion, breach of contract, and fraud. ${ }^{93}$ The court pointed to the Convention on the Recognition and Enforcement of Foreign Arbitral Awards, codified at 9 U.S.C. $\S 201$, and said:

It seems clear that if federal law is to apply, [then] this is the federal law most directly on point. Although the Convention might seem to be directed more to actions to enforce foreign arbitration awards, its provisions deal directly with the issues presently before this court, i.e., the determination of whether or not the arbitration award is final and the effect that such a foreign arbitration award ought to be given in a federal court of the United States. $^{94}$

The court went on to explain that 9 U.S.C. $\S \S 202-03$ confer original jurisdiction on the district court, regardless of the amount in controversy, if

90. Id. at 1178 .

91. Id. at 1179. See also E.I. Dupont de Nemours \& Co. v. Rhone Poulenc Fiber \& Resin Intermediates S.A.S., 269 F.3d 187 (3d Cir. 2001)(addressing the privity requirement of collateral estoppel and describing other related doctrines, including equitable estoppel).

92. Hugo Marom Aviation Consultants, Ltd. v. Recon/Optical, Inc., No. 87 C 9273,1991 U.S. Dist. LEXIS 6877 (N.D. Ill. May 20, 1991) and Hugo Marom Aviation Consultants, Ltd. v. Recon/Optical Inc., No. 87 C 9273, 1992 WL 233942 (N.D. Ill. Sept. 15, 1992).

93. Hugo Marom, 1991 LEXIS 6877 at *8, *17-*18

94. Id. at $* 12-* 13$. 
the action arises out of a legal relationship which is considered "commercial." " However, if the relationship is entirely between citizens of the United States, it falls under the Convention only if it "involves property abroad, 'envisages performance or enforcement abroad, or has some reasonable relation with one or more foreign states." to the Israel Arbitration Law to determine if the award was considered final there; when it discovered it was not, the court found that it was not bound by the award, nor was it res judicata as to the parties. ${ }^{97}$ The court acknowledged that other jurisdictions have given unconfirmed arbitration awards preclusive effect. $^{98}$ The Marom court went on to discuss a corporate alter-ego theory involving the three parties, listed the elements for claim and issue preclusion, and found that the Israeli appeal scheduled for later that year would determine which issues were actually determined and essential to the judgment. ${ }^{99}$

In the subsequent opinion, the same court held that the defendant's counterclaims were collaterally estopped since the common issues from the arbitration had been confirmed in Tel Aviv district court under Israeli law. ${ }^{100}$ Denying the defendant's arguments that 1) the award was not yet final because confirmation of other counts was still pending, and 2) the arbitrator failed to apply a clear legal standard, the court said it would not second guess the Israeli district court's determination. ${ }^{101}$

\section{CONCLUSION}

When rightfully applied, preclusion rules balance the need to keep the courthouse doors open for disputes the litigants did not contract to arbitrate with the need to narrow the issues in dispute, lessen trial lengths, and provide rightful repose for the parties. A judge who is most familiar with an older AAA model of arbitration may be particularly uncomfortable with allowing

95. Id. at *13-*14.

96. Id. (quoting 9 U.S.C. $\S 202(1958)$ ).

97. Id. at $* 15-* 18$.

98. Id. at*19 (citing Panza v. Armco Steel Corp., 316 F.2d 69, 70 (3d Cir. 1963) (granting res judicata for steelworkers union arbitration)).

99. Id. at $* 25-* 30$.

100. Hugo Marom Aviation Consultants, Ltd. v. Recon/Optical, Inc., No. 87 C 9273, 1992 WL 233942, at *4-*5 (N.D. Ill. Sept. 15, 1992).

101. Id. at*6. See also Norris v. Grosvenor Mktg. Ltd., 803 F.2d 1281, 1285 (2d Cir. 1986) (upholding summary judgment on basis of collateral estoppel where all claims were resolved in prior arbitration); accord Fotochrome, Inc. v. Copal Co., 517 F.2d 512 (2d Cir. 1975) (also discussing foreign policy arguments). 
arbitral awards to preclude the subsequent judicial proceeding, pointing to the lack of discovery, less formal evidence rules, and compromise verdicts as the norm. Indeed, it may appear that because preclusion rules were fashioned within a judicial framework, they may not be elastic enough to stretch for alternative dispute resolution's processes. Yet at least where international commercial arbitral awards are concerned, the Convention mandates a broader acceptance of these decisions and their ultimate effect.

As the preceding analysis of case law has demonstrated, recognition and enforcement of a foreign arbitral award under the Convention does not automatically result in issue preclusion in subsequent litigation. To reconcile the matter, courts must continue to require all of the traditional elements of collateral estoppel, yet also comport with the Convention and at least respect, if not further, the purposes for which it was entered into: to increase international trade and provide for predictable resolution of legal matters between parties of disparate legal systems in a global economy. First, courts should carefully analyze the issues to determine if they are identical. Second, only parties or their privies should be held to the benefit of their bargain. Next, courts should apply the Convention to determine third, whether such issues were fully and fairly litigated in the prior proceedings and finally, to determine whether the arbitration resulted in a final and valid judgment. This integrated approach of using the U.N. Convention within the traditional collateral estoppel framework would ensure the arbitration's preclusive effect when it is indeed warranted. 